\title{
Combining abilities for agronomic traits and marker-assisted selection for Potato virus $X$ and Potato virus $Y$ resistance
}

\author{
M.L. Guedes ${ }^{1}$, C.A.B.P. Pinto ${ }^{1}$, G.H.M.R. Ribeiro ${ }^{1}$, D.H. Lyra $^{2}$ and \\ O.L.G. Carneiro ${ }^{2}$ \\ ${ }^{1}$ Departamento de Biologia, Universidade Federal de Lavras, Lavras, \\ MG, Brasil \\ ${ }^{2}$ Departamento de Genética, Escola Superior de Agricultura "Luiz de Queiroz", \\ Universidade de São Paulo, Piracicaba, SP, Brasil \\ Corresponding author: M.L. Guedes \\ E-mail: marcioguedesbio@gmail.com \\ Genet. Mol. Res. 15 (3): gmr.15038685 \\ Received March 31, 2016 \\ Accepted May 5, 2016 \\ Published September 16, 2016 \\ DOI http://dx.doi.org/10.4238/gmr.15038685 \\ Copyright (C) 2016 The Authors. This is an open-access article distributed under the terms of \\ the Creative Commons Attribution ShareAlike (CC BY-SA) 4.0 License
}

\begin{abstract}
Disease-resistant potato cultivars with good tuber appearance and desirable agronomic traits are essential for meeting the demands of producers and the market. Attaining these cultivars is the focus of potato breeding programs whose aim is to benefit the productive chain. The purpose of this study was to estimate combining abilities and evaluate potato clones based on tuber appearance, yield, and resistance to the PVY and PVX viruses. Crosses between four commercial cultivars of potato with good tuber appearance were performed, using eight clones with proven resistance to PVY and PVX from the breeding program of UFLA. The clones obtained were evaluated for agronomic traits, tuber appearance, and the presence of both $R y_{a d g}$ and $R x l$ alleles, which confer extreme resistance to the PVY
\end{abstract}


and PVX viruses, respectively. The independent culling level method was used to select genotypes of commercial interest, as well as to estimate the combining abilities of the parents. We identified clones carrying the $R y_{a d g}$ and $R x l$ alleles with agronomic traits suitable for the fresh market and for processing. The BRS Ana cultivar and CMA-399 and CMA-385 clones showed positive effects on general combining ability (GCA) for tuber yield, while the Monalisa cultivar showed positive effects on GCA for general tuber appearance.

Key words: Solanum tuberosum L; Virus resistance; Potato breeding; PVY; PVX

\section{INTRODUCTION}

Potato is the fourth most important crop produced in the world (FAOSTAT, 2015) and is the largest vegetable crop in Brazil. For consumers, good tuber appearance is one of the primary requirements for new cultivars, and better appearance yields higher sales value. Cultivars introduced from temperate countries, which comprise most of the potatoes grown in Brazil, have good tuber appearance. However, they are deficient in certain traits that were not considered during selection in their countries of origin, such as Potato virus $Y$ (PVY) and Potato virus $X(\mathrm{PVX})$ resistance.

PVY, genus Potyvirus, is transmitted by aphids in the field, and PVX, genus Potexvirus, is mechanically transmitted by contact between plants or by equipment (Palukaitis, 2012). The association between these two viruses causes severe symptoms of rugose mosaic, reducing crop yield by 30 to $100 \%$ (Ávila et al., 2009). An indirect related effect is that farmers must buy certified seed potatoes for each planting, increasing production costs.

Resistance to PVY and PVX is controlled by the $R y_{\text {adg }}$ and $R x l$ alleles, respectively, which provide extreme resistance (Kasai et al., 2000; Ahmadvand et al., 2013), a type of complete resistance that acts in the presence of a single resistance allele (Swiezynski, 1994). Along with the classification of clones according to marketability, identification of individuals that carry both resistance alleles has been the objective of various potato breeding studies (Ribeiro et al., 2006; Andrade et al., 2009). Furthermore, to obtain clones with desirable agronomic traits, disease resistance, and good tuber appearance, it is necessary to identify and choose appropriate parents, as well as to evaluate the performance of these traits and the ability of the parents to transfer favorable alleles. The diallel method with estimation of combining ability has been used to varying degrees for all traits of agronomic importance in potato (Bradshaw and Mackay, 1994; Muthoni et al., 2015). The aim of this study was to estimate combining abilities and evaluate potato clones based on tuber appearance, yield, and resistance to PVY and PVX viruses.

\section{MATERIAL AND METHODS}

\section{Experimental clones}

Crosses were made between four commercial cultivars with good tuber appearance

Genetics and Molecular Research 15 (3): gmr.15038685 
(BRS Ana, Monalisa, Caesar, and Mondial) and eight clones from the plant breeding program of Universidade Federal de Lavras, Lavras, MG, Brazil carrying the $R y_{a d g}$ allele (Andrade et al., 2009). A total of 2500 clones from 24 families were obtained, and all were designated as MLG (Figure 1).

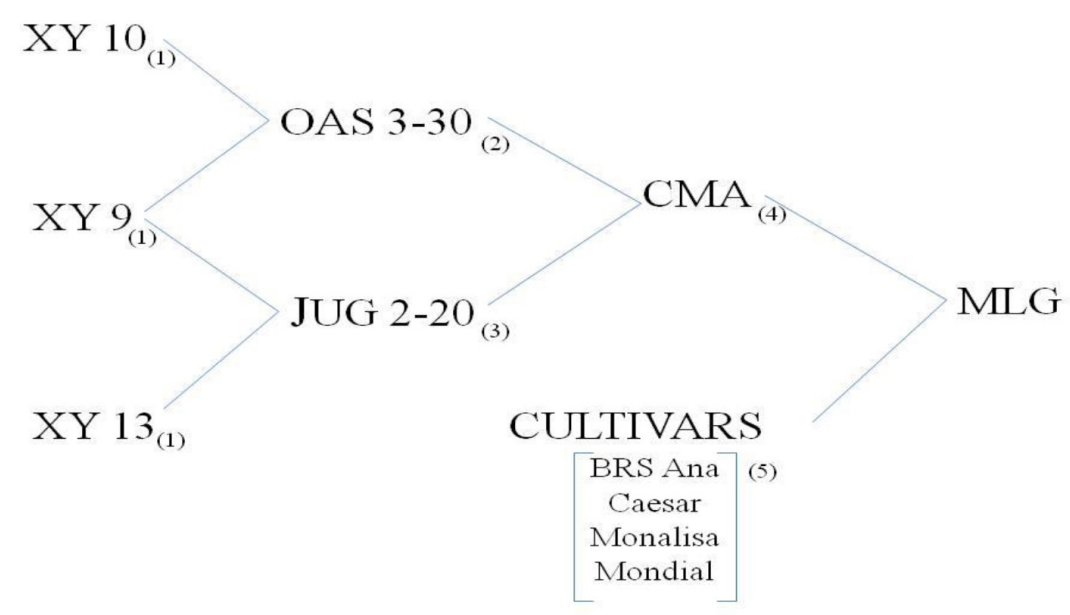

Figure 1. Genealogy of the experimental clones (MLG). Clones identified by: (1) CIP (1989); (2) Silva et al. (2000); (3) Gadum et al. (2003); (4) Andrade et al. (2009); (5) Cultivars (Pereira et al., 2010; ECPD, 2016).

Botanical seeds were treated with gibberellic acid at $1500 \mathrm{ppm}$ to break dormancy, sown in plastic trays, and transplanted after 15 days to $0.5 \mathrm{~L}$ pots in a greenhouse. Tubers were harvested at 70 days after transplanting (seedling generation) and underwent visual selection for general tuber appearance. Clones with irregularly shaped tubers and deep eyes were discarded.

\section{Agronomic evaluation of clonal generations}

In the first clonal generation (FCG), clones selected for general tuber appearance were evaluated for agronomic traits under field conditions in Lavras, MG, Brazil ( $\left.21^{\circ} 22^{\prime} \mathrm{S}-44^{\circ} 98^{\prime} \mathrm{W}\right)$ from May to August 2013 (winter crop season). An augmented block design was used (Federer, 1956) with 1221 clones as regular treatments distributed in 33 blocks, and BRS Ana, Markies, and Asterix cultivars were used as common treatments, for a total of 40 treatments in each block. A plot consisted of two plants spaced at $0.30 \times 0.80 \mathrm{~m}$. Agronomic procedures were performed as for commercial crops in the region.

After harvest, stratified mass selection was undertaken for general tuber appearance, with control plants as a reference. Clones with tubers of irregular shape and deep eyes were discarded. A total of 477 clones were selected and evaluated for the following characteristics: yield of large-sized tubers (transverse diameter greater than $45 \mathrm{~mm}-\mathrm{g} / \mathrm{plant}^{-1}$ ); tuber specific gravity (TSG), calculated as weight in air / (weight in air - weight in water), which was obtained using a hydrostatic balance; general tuber appearance, an average of scores attributed by three evaluators ranging from 1 (tubers with poor appearance) to 5 (tubers with excellent appearance); periderm texture, which was evaluated visually and by touch, with scores ranging 
from 1 (rough periderm) to 5 (smooth periderm); tuber shape as evaluated by visual scores ranging from 1 (round shape) to 5 (long-oblong shape); and eye depth (vegetative sprouts), as evaluated by visual scores ranging from 1 (deep eyes) to 5 (shallow eyes).

For classification and selection of clones, we estimated the adjusted mean values of the clones and used the independent culling level method, which is based on the establishment of minimum or maximum levels for each trait and later selection of the clones whose performance fits within the pre-established limits (Bernardo, 2010). In this way, we established the minimum limit for yield of large tubers as the overall experimental mean. Next, the clones were separated according to market suitability in the following manner: 1) for the fresh market, long-oblong/oval tuber shape, TSG of 1.060 to 1.075, and score for general tuber appearance, periderm texture, and eye depth higher than or equal to the mean value of the checks used in the experiment; and 2) for industrial processing, score for eye depth higher than or equal to that of the checks, TSG higher than or equal to the Asterix check (cultivar used by the potato industry), and round (chips) or long-oblong shape (frozen French fries). By this method, 189 clones were selected as suitable for the market; these underwent molecular analysis to detect the presence of the $R y_{a d g}$ allele.

This second clonal generation (SCG) was grown from February to May 2014 (dry crop season) in a randomized complete block design with three replications and plots of three plants spaced at $0.30 \mathrm{~m} \times 0.80 \mathrm{~m}$. Parents of the experimental clones were also included in this experiment. The Asterix, Atlantic, Ágata, and Cupido cultivars were used as checks. The experiment was conducted and traits evaluated in the same way as for the FCG. After screening, 118 clones were identified and selected for the presence of the $R y_{a d g}$ allele. For classification and selection of clones according to their marketability, the same method of independent culling levels as in the FCG was used, with a final selection of 24 clones.

\section{DNA extraction and molecular marker analysis}

Molecular analysis to detect the presence of the $R y_{a d g}$ allele in the experimental clones was undertaken using the following pair of primers: SCAR RYSC3 (Kasai et al., 2000). DNA was extracted from the tubers using the protocol proposed by Doyle and Doyle (1990). The reaction mixture had a total volume of $12 \mu \mathrm{L}$, comprising $1.2 \mu \mathrm{L}$ buffer for PCR 10X (10 $\mathrm{mM}$ Tris- $\mathrm{HCl}, 50 \mathrm{mM} \mathrm{KCl}, \mathrm{pH} 8.3), 0.6 \mu \mathrm{L}$ Taq DNA polymerase, $1 \mu \mathrm{L} \mathrm{MgCl}_{2}(25 \mathrm{mM})$ plus dNTPs $(10 \mathrm{mM}), 2.25 \mu \mathrm{L}$ primer (SCAR RYSC3), $2 \mu \mathrm{L}$ genomic DNA, and pure water added to a volume of $12 \mu \mathrm{L}$.

Amplifications were carried out in a thermocycler (BIOCYCLER MG96+) with the following programming: $94^{\circ} \mathrm{C}$ for $1 \mathrm{~min}, 33$ cycles of $94^{\circ} \mathrm{C}$ for $1 \mathrm{~min}$, specific annealing temperature of $55^{\circ} \mathrm{C}$ for $30 \mathrm{~s}$ and $72^{\circ} \mathrm{C}$ for $1 \mathrm{~min}$, and finishing at $72^{\circ} \mathrm{C}$ for $7 \mathrm{~min}$. Fragments of DNA were separated on 1\% agarose gel and stained with ethidium bromide for 20 min. The gel was photographed in ultraviolet light. The Chiquita and Monalisa cultivars were used as negative checks (no presence of the $R y_{\text {adg }}$ allele), and simplex clones XY-14 and XY-17 from Centro Internacional de la Papa (CIP) were used as positive checks (presence of the $R y_{\text {adg }}$ allele).

The 24 clones selected in the SCG by the independent culling level method, which were carriers of the $R y_{a d g}$ allele, were analyzed to detect the presence of the $R x l$ allele by the RxSP pair of primers (Ohbayashi et al., 2010). Amplifications were made in a thermocycler (BIOCYCLER MG96+) with the aforementioned programming, with the exception of the

Genetics and Molecular Research 15 (3): gmr.15038685 
annealing temperature, which was $47^{\circ} \mathrm{C}$ for $30 \mathrm{~s}$. The Monalisa cultivar was used as a negative check (no presence of the $R x 1$ allele).

\section{Statistical analysis}

For certification of the homogeneity of the mean squares of errors of all analyses, the Bartlett test was applied. The data obtained from all the traits evaluated in the FCG and SCG were subjected to analysis of variance.

The mean values of the clones selected in the SCG were grouped by the Scott and Knott (1974) test. The environmental coefficient of variation and selective accuracy $\left(\hat{r}_{\hat{g} g}\right)$ were estimated (Resende and Duarte, 2007). Using the adjusted means of the 477 FCG clones, combining abilities were analyzed according to Griffing (1956)'s model IV, and estimates of general combining ability (GCA) and specific combining ability (SCA) were obtained by PROC IML in SAS (Statistical Analysis System, version 9.2). In addition, the coefficients of determination $\left(\mathrm{R}^{2}\right)$ obtained by the ratio between the sum of squares of the combining abilities and the sum of squares of treatments were estimated.

\section{RESULTS}

\section{Field performance of the clonal generations}

In the FCG, significant differences were observed for all traits except general tuber appearance (Table 1). The breakdown of degrees of freedom for the treatments showed that the clones also did not differ from each other in general tuber appearance. Nevertheless, the clone $v s$ control contrast was significant for all traits. The clones exceeded the checks for yield $(22 \%)$ and general tuber appearance $(9 \%)$ (Table 1). By contrast, the checks exceeded the clones for periderm texture (6\%) and eye depth (11\%), and they had more long-oblong tubers. In the SCG, significant differences were observed among clones for all traits, but for the clone vs control comparison, no significant difference was observed for general tuber appearance (Table 2). In both generations, accuracy estimates were of medium to high magnitude for all traits and heritability ranged from 0.21 for general appearance to 0.93 for tuber shape (Tables 1 and 2).

Table 1. Analysis of variance for yield of large tubers, tuber specific gravity, general tuber appearance, periderm texture, eye depth, and tuber shape of the treatments used in the FCG. Lavras, MG, Brazil, 2014.

\begin{tabular}{l|c|c|c|c|c|c|c}
\hline Source of variation & d.f. & \multicolumn{3}{|c}{ Mean square } \\
\cline { 3 - 8 } & & Yield of large tubers $\left(\mathrm{g} /\right.$ plant $\left.^{-1}\right)\left(\mathrm{x} 10^{3}\right)$ & TSG $\left(\mathrm{x} 10^{-4}\right)$ & General appearance & Periderm texture & Eye depth & Tuber shape \\
\hline Treatments & 479 & $158.786^{*}$ & $0.674^{*}$ & $0.232^{\text {ns }}$ & $0.647^{*}$ & $0.360^{*}$ & $0.857^{*}$ \\
\hline Clones & 476 & $138.529^{*}$ & $0.761^{*}$ & $0.222^{\text {ns }}$ & $0.621^{*}$ & $0.463^{*}$ & $0.691^{*}$ \\
\hline Checks & 2 & $5778.570^{*}$ & $12.88^{*}$ & $7.059^{*}$ & $0.412^{\text {ns }}$ & $0.043^{\text {ns }}$ & $2.767^{*}$ \\
\hline Clones $v$ controls & 1 & $531.915^{*}$ & $6.633^{*}$ & $6.752^{*}$ & $37.322^{*}$ & $68.33^{*}$ & $133.89^{*}$ \\
\hline Error & 94 & 90.264 & 0.249 & 0.184 & 0.220 & 0.165 & 0.089 \\
\hline Overall mean & & 741.88 & 1.081 & 2.99 & 2.97 & 3.07 & 3.67 \\
\hline Clone mean & & 742.24 & 1.082 & 3.02 & 2.92 & 3.06 & 3.62 \\
\hline Check mean & & 607.65 & 1.077 & 2.76 & 3.10 & 3.38 & 4.32 \\
\hline Accuracy & & 65.72 & 79.40 & 45.64 & 81.25 & 73.63 & 94.65 \\
\hline CVe $\%$ & 40.71 & 0.52 & 13.91 & 15.21 & 12.50 & 7.72 \\
\hline $\mathrm{h}^{2}$ & & 0.43 & 0.63 & 0.21 & 0.66 & 0.54 & 0.90 \\
\hline
\end{tabular}

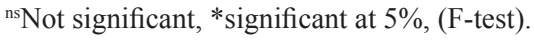

Genetics and Molecular Research 15 (3): gmr.15038685 
Table 2. Analysis of variance for yield of large tubers $\left(\mathrm{g} / \mathrm{plant}^{-1}\right)$, tuber specific gravity, general tuber appearance, periderm texture, eye depth, and tuber shape of the treatments used in SCG. Lavras, MG, Brazil, 2014.

\begin{tabular}{l|c|c|c|c|c|c|c}
\hline Source of variation & \multirow{2}{*}{ d.f. } & \multicolumn{9}{|c}{ Mean square } \\
\cline { 3 - 8 } & & Yield of large tubers $\left(\mathrm{x} 10^{3}\right)$ & TSG $\left(\mathrm{x} 10^{-4}\right)$ & General appearance & Periderm texture & Eye depth & Tuber shape \\
\hline Block & 2 & $2615.914^{* *}$ & $3.935^{* *}$ & $4.524^{* *}$ & $4.109^{* *}$ & $0.274^{*}$ & $0.714^{* *}$ \\
\hline Treatments & 136 & $227.959^{* *}$ & $1.806^{* *}$ & $0.713^{* *}$ & $0.917^{* *}$ & $0.588^{* *}$ & $1.224^{* *}$ \\
\hline Clones & 117 & $214.226^{* *}$ & $1.673^{* *}$ & $0.668^{* *}$ & $0.910^{* *}$ & $0.564^{* *}$ & $1.155^{* *}$ \\
\hline Controls & 3 & $167.043^{\text {ns }}$ & $4.591^{* *}$ & $1.817^{* *}$ & $3.886^{* *}$ & $1.269^{* *}$ & $2.296^{* *}$ \\
\hline Clones $v$ controls & 1 & $1825.382^{* *}$ & $7.629^{* *}$ & $0.161^{\text {ns }}$ & $0.712^{*}$ & $1.435^{* *}$ & $0.500^{*}$ \\
\hline Others & 15 & - & - & - & - & - & - \\
\hline Error & 272 & 66.199 & 0.450 & 0.108 & 0.107 & 0.090 & 0.084 \\
\hline Overall mean & & 616.13 & 1.070 & 3.34 & 3.10 & 3.20 & 3.37 \\
\hline Clone mean & & 658.38 & 1.0687 & 3.37 & 3.11 & 3.18 & 3.35 \\
\hline Control mean & & 261.81 & 1.0606 & 3.49 & 3.36 & 3.53 & 3.56 \\
\hline Accuracy $(\%)$ & & 82.61 & 86.63 & 92.13 & 94.01 & 92.03 & 96.52 \\
\hline CVe $\%$ & & 41.19 & 0.63 & 9.82 & 10.52 & 9.39 & 8.60 \\
\hline $\mathrm{h}^{2}$ & & 0.71 & 0.75 & 0.85 & 0.88 & 0.85 & 0.93 \\
\hline
\end{tabular}

${ }^{\mathrm{n}}$ Not significant, *significant at $5 \%, * *$ significant at $1 \%$, by the $\mathrm{F}$ test.

As in the SCG, the parents of the experimental clones were included in the experiment, so it was possible to compare them as well. On average, the MLG clones exceeded the XY clones for all traits except eye depth and tuber shape. The MLG clones had $73 \%$ higher tuber yield than the XY clones (658.4 vs $379.6 \mathrm{~g} / \mathrm{plant}$ ). However, for TSG, the XY clones had higher results than the experimental clones (1.0732 vs 1.0687).

Comparison of the MLG clones with the JUG+OAS clones should also be noted (Figure 1). Significant differences were found for all traits. The MLG clones had $130 \%$ higher performance for tuber yield and tubers with a more long-oblong shape. Comparison of the MLG clones with the CMA clones (Figure 1) showed a less striking difference in yield (658.4 vs $566.2 \mathrm{~g} / \mathrm{plant}$ ), but more pronounced differences in tuber appearance and periderm texture. For general tuber appearance, the MLG clones had 17\% higher mean values and a smoother periderm. It is noteworthy that the CMA clones were selected by Andrade et al. (2009) by virtue of having two, three, or even four copies of the $R y_{a d g}$ allele, but not for general tuber appearance.

In comparing the MLG clones and the cultivars used as parents (Figure 1), we observed that the mean yield of the experimental clones was approximately 56\% higher (658.4 vs 430.6 $\mathrm{g} / \mathrm{plant})$, whereas for specific gravity, the difference was less striking (1.0687 vs 1.0624). It is noteworthy that significant differences in the appearance of tubers and periderm texture were not detected, although the clones were slightly higher than the MLG clones.

\section{Combining abilities}

The estimates of GCA were higher than those of the SCA, except in general tuber appearance, which explained more than $50 \%$ of the trait variation (Table 3 ). In the case of GCA, the group of clones contributed more than the cultivars to all of the traits except periderm texture and overall tuber appearance (Table 3). Among the clones, the CMA- 80 parent had the worst performance, with negative estimates of GCA for yield and tuber shape traits. By contrast, the CMA-399 parent exhibited the greatest GCA for yield (Table 3). The CMA 37, CMA 370, and CMA 346 clones contributed to more long-oblong tubers, whereas CMA 80, CMA 141, and CMA 385 contributed to more rounded tubers. 
Table 3. Estimates of general combining ability ( $g i)$ of the parents of the group of clones and cultivars of the first clonal generation for yield of large tubers, tuber specific gravity, general tuber appearance, periderm texture, eye depth, and tuber shape. Lavras, UFLA, 2014.

\begin{tabular}{|c|c|c|c|c|c|c|}
\hline \multirow[t]{2}{*}{ Group } & \multicolumn{6}{|c|}{ GCA } \\
\hline & Yield of large tubers ( $\mathrm{g} /$ plant) & TSG & General appearance & \begin{tabular}{|l|} 
Periderm texture \\
\end{tabular} & Eye depth & Tuber shape \\
\hline \multicolumn{7}{|c|}{ 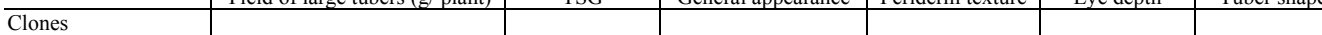 } \\
\hline CMA-399 & 121.91* & 0.00122 & 0.002 & 0.008 & -0.0532 & 0.059 \\
\hline CMA-385 & 52.63 & $-0.00529 *$ & -0.059 & -0.128 & -0.1101 & $-0.263 *$ \\
\hline CMA-370 & 5.89 & 0.00174 & -0.002 & -0.129 & 0.1157 & $0.406^{*}$ \\
\hline CMA-37 & 47.83 & -0.00100 & 0.132 & 0.054 & 0.2106 & $0.416^{*}$ \\
\hline CMA-346 & 35.39 & -0.00001 & -0.025 & 0.079 & 0.1354 & $0.279^{*}$ \\
\hline CMA-80 & $-202.01 *$ & -0.00167 & -0.101 & 0.164 & 0.0725 & $-0.307^{*}$ \\
\hline CMA-141 & -73.03 & 0.00155 & -0.005 & -0.008 & -0.1067 & $-0.267 *$ \\
\hline CMA-270 & -86.32 & $0.00553 *$ & 0.124 & 0.112 & -0.1132 & -0.139 \\
\hline \multicolumn{7}{|l|}{ Cultivars } \\
\hline Monalisa & -46.37 & $-0.00263 *$ & $0.132 *$ & $0.163 *$ & 0.0192 & $-0.210 *$ \\
\hline Caesar & -53.63 & -0.00119 & -0.022 & $-0.307^{*}$ & 0.0060 & -0.060 \\
\hline Mondial & 14.05 & 0.00145 & $-0.176^{*}$ & $0.226^{*}$ & 0.0008 & $0.245^{*}$ \\
\hline BRS Ana & $68.18^{*}$ & $0.00218^{*}$ & -0.009 & 0.048 & -0.0181 & 0.101 \\
\hline $\mathrm{R}^{2}$ (GCA - Clones) & $47.74 \%$ & $63.82 \%$ & $19.10 \%$ & $18.52 \%$ & $61.95 \%$ & $65.44 \%$ \\
\hline $\mathrm{R}^{2}$ (GCA - Cultivars) & $16.73 \%$ & $23.31 \%$ & $27.33 \%$ & $60.94 \%$ & $0.92 \%$ & $17.73 \%$ \\
\hline $\mathrm{R}^{2}$ (SCA) & $35.83 \%$ & $12.92 \%$ & $53.64 \%$ & $20.65 \%$ & $37.33 \%$ & $16.92 \%$ \\
\hline
\end{tabular}

*Significant at $5 \%$ by the $\mathrm{F}$ test.

Among the cultivars, BRS Ana exhibited higher GCA for yield and also for TSG (Table 3). The Monalisa cultivar exhibited higher positive GCA for tuber appearance and periderm texture, making its siblings more suitable for the fresh market segment. However, it had negative GCA for TSG, indicating low frying performance. In addition, Monalisa tended to generate siblings with more oval tubers, since its GCA was negative for tuber shape. The Mondial cultivar worsened overall tuber appearance (negative GCA), but contributed to the generation of descendants with more long-oblong tubers (positive GCA for tuber shape).

\section{Clone selection}

Selection by means of the independent culling level method used in this study allowed the selection of genotypes with potential within the limits pre-established for each trait (Table 4). Selection based on agronomic traits, general tuber appearance, and resistance to PVY and PVX retained 24 clones. DNA extraction from tubers provided results as reliable as leaf extraction for analysis of the $R y_{\text {adg }}$ and $R x l$ alleles.

The highest-yielding clones went beyond $1.0 \mathrm{~kg} / \mathrm{plant}$ and exceeded the highestyielding check (Atlantic cultivar). The MLG 04-11 clone exhibited a 65\% higher yield than Atlantic and, moreover, had a round shape, which is ideal for the chip industry. Some clones had excellent tuber appearance, similar to the Ágata cultivar, and therefore have potential for the fresh market in addition to exhibiting higher TSG, which leads to better quality for frying.

The MLG 02-12, MLG 20-12, MLG 22-23, and MLG 23-24 clones exhibited the best yield and contained the $R y_{a d g}$ and $R x 1$ alleles (Table 4). The MLG 02-12 clone had better qualities for the fresh market, while the other three showed potential for both the fresh market and industry.

\section{DISCUSSION}

Comparison of heritability between FCG and SCG showed that there is higher genetic

Genetics and Molecular Research 15 (3): gmr.15038685 
Table 4. Mean values of the clones selected in the second clonal generation and checks for yield of large tubers (g/ plant), tuber specific gravity, general tuber appearance, periderm texture, eye depth, and tuber shape, as well as the presence of the $R y_{\text {adg }}$ e $R x l$ alleles and marketability. Lavras, UFLA, 2014.

\begin{tabular}{|c|c|c|c|c|c|c|c|c|c|}
\hline Clone & $\begin{array}{c}\begin{array}{c}\text { Yield of large tubers } \\
\text { (g/plant })\end{array} \\
\end{array}$ & TSG & $\begin{array}{l}\text { Tuber } \\
\text { shape }\end{array}$ & $\begin{array}{c}\text { Periderm } \\
\text { texture }\end{array}$ & Eye depth & \begin{tabular}{|c} 
General \\
appearance
\end{tabular} & Presence of Ryadg & Presence of $R x 1$ & Marketability \\
\hline$\overline{\text { MLG-01.02 }}$ & $1005.56^{\mathrm{a}}$ & $1.0659^{\mathrm{c}}$ & $3.78^{\circ}$ & $3.44^{\mathrm{b}}$ & $3.00^{\mathrm{c}}$ & $3.50^{\mathrm{b}}$ & + & - & Fresh market \\
\hline MLG-01.06 & $1088.89^{\mathrm{a}}$ & $1.0688^{\mathrm{b}}$ & $3.89^{\mathrm{c}}$ & $2.78^{\mathrm{d}}$ & $3.56^{\mathrm{b}}$ & $4.00^{\mathrm{a}}$ & + & - & French fries/fresh market \\
\hline MLG-02.12 & $788.89^{\mathrm{a}}$ & $1.0651^{\mathrm{c}}$ & $3.39^{\mathrm{c}}$ & $3.44^{\mathrm{b}}$ & $3.33^{\mathrm{b}}$ & $3.44^{\mathrm{b}}$ & + & + & Fresh market \\
\hline MLG-03.03 & $1200.00^{\mathrm{a}}$ & $1.0715^{\mathrm{b}}$ & $3.44^{\circ}$ & $3.11^{\mathrm{c}}$ & $3.56^{\mathrm{b}}$ & $4.17^{\mathrm{a}}$ & + & - & French fries/fresh market \\
\hline$\overline{\text { MLG-04.11 }}$ & $983.33^{\mathrm{a}}$ & $1.0716^{\mathrm{b}}$ & $2.33^{\mathrm{f}}$ & $3.56^{\mathrm{b}}$ & $2.56^{\mathrm{d}}$ & $3.50^{\mathrm{b}}$ & + & - & Chips \\
\hline MLG-04.26 & $966.67^{\mathrm{a}}$ & $1.0653^{\mathrm{c}}$ & $4.11^{\mathrm{b}}$ & $3.44^{\mathrm{b}}$ & $3.11^{\mathrm{c}}$ & $3.61^{\mathrm{b}}$ & + & - & Fresh market \\
\hline MLG-04.44 & $872.22^{\mathrm{a}}$ & $1.0685^{\mathrm{b}}$ & $3.67^{\mathrm{c}}$ & $2.67^{\mathrm{d}}$ & $3.44^{\mathrm{b}}$ & $3.94^{\mathrm{a}}$ & + & - & French fries/fresh market \\
\hline$\overline{\text { MLG-05.01 }}$ & $755.56^{\mathrm{b}}$ & $1.0715^{\mathrm{b}}$ & $3.67^{\circ}$ & $2.78^{\mathrm{d}}$ & $3.00^{\mathrm{c}}$ & $3.33^{\mathrm{c}}$ & + & - & French fries \\
\hline$\overline{\text { MLG-09.03 }}$ & $783.33^{\mathrm{a}}$ & $1.0793^{\mathrm{a}}$ & $3.78^{\mathrm{c}}$ & $3.78^{\mathrm{a}}$ & $3.56^{\mathrm{b}}$ & $3.89^{\mathrm{a}}$ & + & - & French fries/fresh market \\
\hline MLG-11.05 & $811.11^{\mathrm{a}}$ & $1.0736^{\mathrm{b}}$ & $3.56^{\mathrm{c}}$ & $1.00 \mathrm{f}$ & $3.44^{\mathrm{b}}$ & $3.33^{\mathrm{c}}$ & + & - & French fries \\
\hline MLG-11.10 & $1005.56^{\mathrm{a}}$ & $1.0761^{\mathrm{b}}$ & $3.67^{\circ}$ & $3.78^{\mathrm{a}}$ & $3.78^{\mathrm{a}}$ & $3.83^{\mathrm{b}}$ & + & - & French fries/fresh market \\
\hline MLG-11.45 & $772.22^{\mathrm{a}}$ & $1.0709^{\mathrm{b}}$ & $3.22^{\mathrm{d}}$ & $1.78^{\mathrm{e}}$ & $3.11^{\mathrm{c}}$ & $3.00^{\mathrm{c}}$ & + & - & French fries \\
\hline MLG-12.16 & $194.44^{\mathrm{a}}$ & $1.0707^{\mathrm{b}}$ & $3.33^{\mathrm{c}}$ & $2.67^{\mathrm{d}}$ & $3.22^{\mathrm{b}}$ & $4.06^{\mathrm{a}}$ & + & - & French fries/fresh market \\
\hline MLG-14.12 & $827.78^{\mathrm{a}}$ & $1.0743 \mathrm{~b}$ & $4.22^{\mathrm{b}}$ & $2.78^{\mathrm{d}}$ & $3.00^{\mathrm{c}}$ & $2.94^{\mathrm{c}}$ & + & - & French fries \\
\hline MLG-17.48 & $1050.00^{\mathrm{a}}$ & $1.0680 \mathrm{~b}$ & $3.89^{\mathrm{c}}$ & $2.89^{\mathrm{c}}$ & $3.11^{\mathrm{c}}$ & $2.89^{\mathrm{d}}$ & + & - & French fries \\
\hline MLG-17.50 & $927.78^{\mathrm{a}}$ & $1.0783 \mathrm{a}$ & $4.11^{\mathrm{b}}$ & $3.44^{\mathrm{b}}$ & $3.00^{\mathrm{c}}$ & $3.83^{\mathrm{b}}$ & + & - & French fries/ fresh market \\
\hline MLG-20.01 & $966.67^{\mathrm{a}}$ & $1.0724 \mathrm{~b}$ & $3.22^{\mathrm{d}}$ & $3.56^{\mathrm{b}}$ & $3.00^{\mathrm{c}}$ & $3.78^{\mathrm{b}}$ & + & - & French fries/ fresh market \\
\hline MLG-20.12 & $683.33^{\mathrm{b}}$ & $1.0838 \mathrm{a}$ & $3.33^{\mathrm{c}}$ & $3.11^{\mathrm{c}}$ & $3.89^{\mathrm{a}}$ & $3.72^{\mathrm{b}}$ & + & + & French fries/ fresh market \\
\hline$\overline{\text { MLG-20.14 }}$ & $683.33^{\mathrm{b}}$ & $1.0785 \mathrm{a}$ & $4.00^{\mathrm{b}}$ & $2.56^{\mathrm{d}}$ & $3.00^{\mathrm{c}}$ & $2.83^{\mathrm{d}}$ & + & - & French fries \\
\hline MLG-20.17 & $911.11^{\mathrm{a}}$ & $1.0700 \mathrm{~b}$ & $3.44^{\mathrm{c}}$ & $2.33^{\mathrm{d}}$ & $3.78^{\mathrm{a}}$ & $3.83^{\mathrm{b}}$ & + & - & French fries/ fresh market \\
\hline MLG-22.23 & $761.11^{\mathrm{a}}$ & $1.0930 \mathrm{a}$ & $4.00^{\mathrm{b}}$ & $4.11^{\mathrm{a}}$ & $3.56^{\mathrm{b}}$ & $4.28^{\mathrm{a}}$ & + & + & French fries/ fresh market \\
\hline MLG-23.24 & $1638.89^{\mathrm{a}}$ & $1.0749 \mathrm{~b}$ & $4.67^{\mathrm{a}}$ & $3.11^{\mathrm{c}}$ & $3.67^{\mathrm{a}}$ & $3.50^{\mathrm{b}}$ & + & + & French fries/ fresh market \\
\hline MLG-23.37 & $738.89^{\mathrm{a}}$ & $1.0728 \mathrm{~b}$ & $3.44^{\mathrm{c}}$ & $3.33^{\mathrm{c}}$ & $3.33^{\mathrm{b}}$ & $4.06^{\mathrm{a}}$ & + & - & French fries/ fresh market \\
\hline MLG-24.36 & $783.33^{\mathrm{a}}$ & $1.0760 \mathrm{~b}$ & $4.00^{\mathrm{b}}$ & $3.33^{\mathrm{c}}$ & $3.33^{\mathrm{b}}$ & $3.72^{\mathrm{b}}$ & + & - & Fresh market \\
\hline Ágata & $144.44^{\mathrm{c}}$ & $1.0515 \mathrm{~d}$ & $3.67^{\mathrm{c}}$ & $3.78^{\mathrm{a}}$ & $3.78^{\mathrm{a}}$ & $3.50^{\mathrm{b}}$ & - & - & Fresh market \\
\hline Asterix & $55.56^{\mathrm{c}}$ & $1.0677 \mathrm{~b}$ & $4.67^{\mathrm{a}}$ & $3.89^{\mathrm{a}}$ & $3.89^{\mathrm{a}}$ & $3.33^{\mathrm{c}}$ & - & - & French fries \\
\hline Atlantic & $594.44^{\mathrm{b}}$ & $1.0744 \mathrm{~b}$ & $2.56^{\mathrm{e}}$ & $1.67^{\mathrm{e}}$ & $2.56^{\mathrm{d}}$ & $2.61^{\mathrm{d}}$ & - & + & Chips \\
\hline Cupido & $252.78^{\mathrm{c}}$ & $1.0490 \mathrm{~d}$ & $3.33^{\mathrm{c}}$ & $4.11^{\mathrm{a}}$ & $3.89^{\mathrm{a}}$ & $4.50^{\mathrm{a}}$ & - & - & Fresh market \\
\hline
\end{tabular}

"+" = presence of the band, "-" = absence of the band. Presence of Rxl for Atlantic (Ahmadvand et al., 2013). Mean values followed by different letters in the column differ by the Scott-Knott test at 5\% probability.

variation in the SCG for all traits that can increase selection gain. Ticona-Benavente and da Silva Filho (2014) recommended not selecting clones based on the FCG; it is only necessary to evaluate clones from the SCG, in which there are more plants per clone.

The mean value of TSG of the clones was equivalent to a dry matter content of $22 \%$, whereas for the checks, dry matter content was approximately $21 \%$ (Table 1). Although this difference may seem small, on an industrial scale, it results in higher yield of the final product (chips or French fries). The mean values of yield and TSG were lower in the SCG than in the FCG (Tables 1 and 2). This result probably reflected the effect of higher temperatures that occurred during growth of the SCG (dry crop season), whereas the FCG was grown during the winter crop season.

Clones XY that originated from CIP (Figure 1) have Solanum andigena in their genealogy, as they are more primitive materials. They are resistant to PVX and PVY in the simplex condition, and also resistant to early blight (Alternaria solani) and heat tolerant (CIP, 1989). The result of crossing MLG clones with JUG+OAS clones was expected since clones OAS 3-30 and JUG 2-20 were selected only on the basis of their duplex condition for the $R y_{a d g}$ allele, which leads to the production of siblings with a higher probability of inheriting the resistance allele (Ribeiro et al., 2006).

The clones obtained in this study were higher than one parent for all traits. When comparing the means of the MLG clones with those of the CMA parents, there was higher performance for traits related to the appearance of tubers. Therefore, cultivars used as parents

Genetics and Molecular Research 15 (3): gmr.15038685 
should improve tuber appearance, making them more desirable for fresh marketing.

SCA tends to be more important than GCA in crosses involving related parents (Neele et al., 1991). However, that was not the case in this study since the parent cultivars, which came from Holland, do not have any kinship to the clones used in the crosses. According to Bradshaw and Mackay (1994), when there is a predominance of GCA, the mean value of the parental lines can be a good alternative for predicting progeny performance.

No parent was found with high GCA for all traits. For overall tuber appearance and periderm texture, the Monalisa cultivar stands out as a good parent for potato breeding with a view toward the fresh market. For yield, the BRS Ana cultivar and the CMA-399 and CMA385 clones are recommended as the best parents due to their high positive GCA as well as the presence of $R y_{a d g}$ and $R x 1$ alleles for resistance to viruses.

Viruses PVY and PVX are harmful to potato crops, and their simultaneous occurrence has severe synergistic effects leading to production losses (Palukaitis, 2012). Therefore, clones resistant to these two diseases were selected in this study.

It is noteworthy that for resistance to the $\mathrm{Y}$ and $\mathrm{X}$ viruses, where the presence of only one copy of the alleles is easily identified through molecular markers, early selection can and must be used. Furthermore, in the initial generations, DNA from recently harvested tubers can be extracted and the presence of resistance alleles evaluated in order to carry only resistant genotypes to the following generation.

MLG clones showed resistance to PVX and PVY, making them potentially useful in potato breeding programs and as parents of new populations as well as for possible release as new cultivars.

\section{Conflicts of interest}

The authors declare no conflict of interest.

\section{ACKNOWLEDGMENTS}

Research supported by CNPq, FAPEMIG, and CAPES.

\section{REFERENCES}

Ahmadvand R, Wolf I, Gorji AM, Polgár Z, et al. (2013). Development of molecular tools for distinguishing between the highly similar Rx1 and Rx2 PVX extreme resistance genes in tetraploid potato. Potato Res. 56: 277-291. http:// dx.doi.org/10.1007/s11540-013-9244-y

Andrade CM, Pinto CABP, Ribeiro SRRP, Peixouto LS, et al. (2009). Potato clones with multiple copies of the $R y_{a d g}$ allele conferring resistance to PVY. Crop Breed. Appl. Biot. 9: 286-292. http://dx.doi.org/10.12702/1984-7033.v09n04a01

Ávila AC, Melo PE, Leite LR and Inoue-Nagata AK (2009). Ocorrência de vírus em batata em sete estados do Brasil. Hortic. Bras. 27: 490-497. http://dx.doi.org/10.1590/S0102-05362009000400015

Bradshaw JE and Mackay GR (1994). Breeding strategies for clonally propagated potatoes. In: Potato genetics (Bradshaw JE and Mackay GR, eds.). Center for Agriculture and Biosciences International, Oxfordshire, 467-497.

Bernardo R (2010). Breeding of quantitative traits. Stemma Press. Woodbury.

CIP (1989). Center International De La Papa, Annual Report. Lima.

Doyle JJ and Doyle JL (1990). Isolation of plant DNA from fresh tissue. Focus. 12: 13-15.

ECPD (2016). The European Cultivated Potato Database. Available at: https://www.europotato.org/menu.php. Accessed May 03, 2016.

FAOSTAT (2015). Food and Agriculture Organization of the United Nations Statistics. Available at [http://faostat.fao.org/

Genetics and Molecular Research 15 (3): gmr.15038685 
site/562/default.aspx]. Accessed May 17, 2015.

Federer WT (1956). Augmented designs. Hawaii Plant. Rec. 40: 191-207.

Gadum J, Pinto CABP and Rios MCD (2003). Desempenho agronômico e reação de clones de batata (Solanum tuberosum L.) ao PVY. Cienc. Agrotec. 1: 484-1492.

Griffing B (1956). Concept of general and specific combining abilities in relation to diallel crossing systems. Aust. J. Biol. Sci. 9: 463-493.

Kasai K, Morikawa Y, Sorri VA, Valkonen JPT, et al. (2000). Development of SCAR markers to the PVY resistance gene $R y_{\text {adg }}$ based on a common feature of plant disease resistance genes. Genome 43: 1-8. http://dx.doi.org/10.1139/ gen-43-1-1

Muthoni J, Shimelis H and Melis R (2015). Combining ability analysis of tuber yield and related traits and bacterial wilt ('Ralstonia solanacearum') resistance in potato. Aust. J. Crop Sci. 9: 401-412.

Neele AEF, Nab HJ and Louwes KM (1991). Identification of superior parents in a potato breeding programme. Theor. Appl. Genet. 82: 264-272. http://dx.doi.org/10.1007/BF02190611

Ohbayashi K, Nakata N, Chaya M and Komura K (2010). Development of a detection method of resistance to potato disease and pest using DNA markers 1. Detection methods of resistance to potato virus $\mathrm{X}$, potato cyst nematode and late blight. Bull. Nagasaki Agri. Fore. Technol. Dev. Cen. 1: 1-26.

Palukaitis P (2012). Mini-Reviews: Resistance to viruses of potato and their vectors. Plant Pathol. 28: 248-258. http:// dx.doi.org/10.5423/PPJ.RW.06.2012.0075

Pereira ADS, Bertoncini O, Castro CM, Melo PED, et al. (2010). BRS ANA: A dual purpose potato cultivar. Hortic. Bras. 28: 500-505. http://dx.doi.org/10.1590/S0102-05362010000400021

Resende MDV and Duarte JB (2007). Precisão e controle de qualidade em experimentos de avaliação de cultivares. Pesq. Agropec. Trop. 37: 182.

Ribeiro AM, Pinto CABP, Andrade CM, Santos J, et al. (2006). SCAR marker for the selection of $R y$-duplex potato clones immune to Potato Virus Y. Crop Breed. Appl. Biot. 1: 1-8. http://dx.doi.org/10.12702/1984-7033.v06n01a01

Scott A and Knott M (1974). Cluster-analysis method for grouping means in analysis of variance. Biometrics 30: 507-512. http://dx.doi.org/10.2307/2529204

Silva AO, Pinto CABP and Figueira AR (2000). Identificação de clones de batata imunes aos vírus X e Y, adaptados à região sul de Minas Gerais. Sum. Phytopathol. 26: 385-390.

Swiezynski KM (1994). Inheritance to resistance to viruses. In: Potato genetics (Bradshaw JE and Mackay GR, eds.). Center for Agriculture and Biosciences International, Wallingford.

Ticona-Benavente CA and da Silva Filho FD (2014). Comparison of BLUE and BLUP/REML in the selection of clones and families of potato (Solanum tuberosum). Genet. Mol. Res. 14: 18421-18430. http://dx.doi.org/10.4238/2015. December.23.30 